\title{
En attendant Sarko? France's mainstream Right and Centre, 2012-2014
}

Article

Accepted Version

Knapp, A. (2014) En attendant Sarko? France's mainstream Right and Centre, 2012-2014. Modern and Contemporary France, 22 (4). pp. 473-489. ISSN 0963-9489 doi:

https://doi.org/10.1080/09639489.2014.957963 Available at https://centaur.reading.ac.uk/38079/

It is advisable to refer to the publisher's version if you intend to cite from the work. See Guidance on citing.

Published version at: http://dx.doi.org/10.1080/09639489.2014.957963

To link to this article DOI: http://dx.doi.org/10.1080/09639489.2014.957963

Publisher: Routledge

All outputs in CentAUR are protected by Intellectual Property Rights law, including copyright law. Copyright and IPR is retained by the creators or other copyright holders. Terms and conditions for use of this material are defined in the End User Agreement.

\section{www.reading.ac.uk/centaur}

\section{CentAUR}

Central Archive at the University of Reading

Reading's research outputs online 


\section{En attendant Sarko? France's mainstream Right and Centre,}

\section{2-2014}

\section{Andrew Knapp, University of Reading}

The municipal elections of 23 and 30 March 2014 gave the French Right and Centre their first electoral victory in nearly seven years. Between them, the Union pour un Mouvement Populaire (UMP) of former president Nicolas Sarkozy, and the 'Alternative', a centrist grouping of the Union des Démocrates et Indépendants (UDI) and the Mouvement des Démocrates (MoDEM), took 57 out of France's 251 towns of over 30,000 inhabitants (including nine of over 100,000) from left-wing incumbents. This triumph chiefly benefited the UMP, which won nine of the ten big town halls, and whose mayors in towns of over 9,000 inhabitants outnumber those of the UDI by 320 to 115 (Le Monde, 31 March 2014). But it also demonstrated a functional alliance between the two groupings. Less than two years after Sarkozy's defeat by François Hollande at the 2012 presidential election, and the ensuing loss of the UMP's majority at the parliamentary elections that June, the UMP and its centrist allies almost looked like a revived opposition poised for a speedy return to power. The UMP's president, Jean-François Copé, could boast his own easy re-election as mayor of Meaux, his party's recaptured status as France's leading political force, and the youth and vigour of its new generation of mayors (Le Monde, 1 April 2014).

Yet at the European elections of 25 May 2014, the UMP lost 9 of its 29 MEPs and a quarter of its vote (which dropped to 20.81 per cent from 27.88 per cent in 2009). UMP lists came first in just five out of France's 22 regions (Île-de-France, Brittany, Auvergne, Corsica, and, narrowly, Pays de la Loire). While the Centrists' more modest ambitions were satisfied with their 9.94 per cent and 7 seats, the main victor was undoubtedly Marine Le Pen's far-right Front National (FN), with 24.86 per cent overall and the lead in 16 regions (Le Monde, 27 
May 2014). Only by adding the Centre and the UMP together could the moderate opposition still be considered as leading the FN. Less than 48 hours after the results were announced, Copé had been forced to stand down as party president (Le Monde, 28 May 2014).

Two dramatically different outcomes just two months apart: but also two very different types of election. The municipal contest rewards grass-roots implantation; European elections often favour extremes against moderates. But the results also say much about the successes and failures of the UMP and Centre two years into the Hollande presidency.

Any party finding itself newly in opposition, especially after a full decade in power, faces a broadly comparable set of tasks: settling the leadership question; developing not only a convincing critique of the new government but also an attractive political project; dealing with its own past record; re-engaging with civil society; reviewing and perhaps changing relations with allies and competitors (Kolinsky, 1987, 1-7). Landing blows on the hapless Hollande and his Socialist majority, whose support collapsed even faster than that of their right-wing predecessors, was easy. The French Right and Centre have also undertaken their own reconstruction, with some success. At the same time, both suffer from historic ills: from their weak institutionalisation, from uncertainties about their leadership, identity, and strategy, and in the UMP's case, from the taint of scandal.

A partial reconstruction (A-Head)

Three aspects marked the partial reconstruction of the Right and Centre after 2012. First, the UMP reaffirmed the solidly right-wing identity set out in the later Sarkozy presidency.

Second, and more indirectly, it benefited from a series of social movements that gathered pace in opposition to government policies during 2013. Third, the diverse Centre parties regrouped into a loose alliance and clarified their future strategy. 
The UMP's projet d'alternance (B-head)

At his election in 2007, Sarkozy had leavened his conservative government with ministers from the Left. But they had gone by November 2010; and the president set an increasingly right-wing, populist course that reached a climax towards the close of his 2012 campaign. UMP moderates, blaming Sarkozy's inner circle, ascribed his defeat to this line (Le Monde, 6 May 2012; Bachelot, 2012, 169-170). More detached analysts have seen the strategy as the only way to persuade Marine Le Pen's first-round voters to switch to Sarkozy for the run-off (Piar, 2012, 39; Chiche and Dupoirier, 2012, 210-211). Sarkozy’s right-wing supporters pointed out that he had nearly closed Hollande's early poll lead, and claimed that two more weeks' campaigning would have secured his re-election. From this viewpoint, Sarkozy's (narrow) defeat became a moral victory, his policies justified by events and in need of systematisation not change.

This was the task Copé assigned to Hervé Mariton, the solidly right-wing Deputy for the Drôme who became the party's délégué general au projet from December 2012. Mariton organised a series of thematic conventions during 2013, covering immigration, defence, policing, pensions, business and labour deregulation, taxation, the family (including opposition to same-sex marriage), the disabled, and Europe (UMP, 2014a). Their conclusions flowed into a projet d'alternance, ratified by the party's National Council on 25 January 2014. It included, for example, a 'final end' to the 35-hour working week instituted by the Socialists fifteen years earlier; public spending cuts worth 130 billion euros; a social housing sell-off; limits to immigrants' rights to be joined by family members; and a rise in the retirement age to 65 from 2023 (UMP, 2014b). 
The programme, somewhat less economically radical, more European, and more socially conservative than that of the British Conservatives, offered no big innovations compared to earlier French right-wing platforms (RPR, 1984). But it was not really intended to; this was, to quote the title of Copé's book, a Manifeste pour une droite décomplexée (Copé, 2012), set to continue the Sarkozy presidency, though not necessarily with Sarkozy in charge.

The extra-parliamentary opposition (B-head)

Unremarkably for a party newly in opposition, the UMP spent much of 2013 looking inwards. But the opposition repeatedly filled French streets that year: not primarily party militants, but activists who joined new, sometimes ephemeral, social movements reacting to the Left's policies in power. Indirectly, they offered the UMP a valuable opportunity to connect with civil society.

Street demonstrations have traditionally been viewed as a typically left-wing phenomenon, offensive to the Right's penchant for public order (Tartakowsky, 2013, 8-10, 146). Yet under the Fifth Republic, the Right has achieved significant successes on the street. In spring 1984, for example, vast demonstrations secured the withdrawal of a bill regulating private (Catholic) schooling, and toppled first Education Minister Alain Savary and then the whole government.

That mobilisation had been greatly assisted by the Church. So was the biggest right-wing social movement of 2013, the 'Manif pour tous', a campaign of protest against the government's bill allowing same-sex marriage. Tabled in the National Assembly on 29 January, the bill fulfilled one of Hollande's campaign promises. Opinion polls showed that 60 per cent of the French favoured it (though they were less sure about adoption by same-sex couples) (IFOP, 2013b, 2013c, 2013d). For the unpopular Hollande, this was an apparent 
opportunity to remobilise his own camp and to isolate the Right. The scale of opposition was therefore surprising: on 17 November 2012, as the government finalised the bill, 70,000 demonstrators were in the streets of Paris; on 13 January 2013 there were 340,000 according to the police, 800,000 according to the organisers; on 24 March the figures were 300,000 and 1.4 million, and on 26 May there were still 150,000. By that time the bill, including adoption rights, had become law; the first gay marriage took place on 29 May.

The movement had had secular and almost modish beginnings, down to the hitherto leftish term manif. Its first spokesperson, Virginie Tellenne (aka Frigide Barjot), an occasional rock performer and stand-up comic for over two decades, had excellent media contacts. Wealthy Catholics such as Claude Bébéar, former head of AXA, used her to shake off the image of Catholic activists as well-heeled and fusty traditionalists. But the Manif pour tous also attracted support from the Catholic hierarchy (including André Vingt-Trois, CardinalArchbishop of Paris), and from a broad constellation of right-wing traditionalist and far-right groups. Barjot herself disowned the movement in May 2013 when activists turned from opposition to gay marriage to more general attacks on homosexuals (Canard Enchaîné, 2013, $6-7)$.

Failing to prevent gay marriage, the protests still achieved two things. First, they effectively blocked further measures offensive to traditional views of the family, in particular surrogate parenting and assisted reproductive technology. A brief, small-scale revival of the Manif pour tous on 2 February 2014 was enough for the government to shelve a further family law, to the consternation of the Socialist majority. Second, the protests offered opportunities to rightwing parties. These were not picked up unhesitatingly. In the FN, Marine Le Pen's former rival Bruno Gollnisch attended the January demonstration; Le Pen herself, who counts several gay advisers, did not. Moderates in the UMP leadership like François Fillon and Alain Juppé stayed away. But Copé took part in January, and Mariton marched in April, arm-in-arm with 
Gilbert Collard, an FN Deputy. More important, perhaps, the movement initiated tens of thousands of (often young) recruits into right-wing activism (Tartakowsky, 2013, 193). For Sarkozy’s adviser Patrick Buisson, self-confessed reactionary and admirer of Joseph de Maistre, it was in 'perfect continuity' with the 2012 campaign; for Brice Hortefeux, Sarkozy's former Interior Minister and close confidant, the Manif pour tous was a 'seedbed' of future militants (Canard Enchaîné, 2013, 9, 37).

So, potentially, were the other movements that flourished in Hollande's first 18 months in power, notably the 'pigeons' (small entrepreneurs opposed to the Left's taxation policies) and the Bonnets Rouges, a Brittany-based collective organised against the planned carbon tax. Neither was led by the UMP, though both included individual party members; above all, the electronic media on which the movements' speedy constitution depended also offered UMP activists valuable networks for future election campaigns (Le Monde, 29 October, 13 and 22 November 2013).

A re-emergent Centre (B-head)

Meanwhile the UMP's leadership crisis of 2012, detailed below, and its increasingly rightward leanings, opened space for a revived Centre (Perrineau, 2012). Squeezed by the Fifth Republic's bipolarised party system, the Centre has faced the constant challenge of remaining independent while maintaining the alliances necessary to win office (Knapp, 2004, 199-233). In 2002, most Centre politicians had joined the newly-formed UMP, some of them, in the Parti Radical, with a distinct status. Only a minority, led by François Bayrou, remained independent, in what remained of the Union pour la Démocratie Française (UDF), the centreright grouping founded in 1978 by Valéry Giscard d'Estaing. Bayrou's strategy, to make the UDF a 'hyper-centre', independent of UMP and Socialists alike, brought him the historically impressive score of 18.6 per cent at the 2007 presidential elections. But he still failed to reach 
the run-off. On Sarkozy's election most remaining UDF parliamentarians, led by Sarkozy's new defence minister Hervé Morin, left to form the Nouveau Centre, in effect a UMP satellite. Bayrou, almost alone, carried on with the rump of the UDF, renamed the MoDem.

The early Hollande presidency narrowed, though without ending, the centrists' divisions. First, Bayrou abandoned the 'hyper-centrist' strategy: he had little alternative, given his score of 9.1 per cent, half of his 2007 figure, on 22 April 2012, the isolation that followed his declaration of support for Hollande at the second ballot, and the ensuing loss of his parliamentary seat in June. Meanwhile, the Parti Radical and the Nouveau Centre moved out of the UMP orbit. Jean-Louis Borloo, leader of the Parti Radical and Ecology Minister under Sarkozy from 2007 to 2010, had broken his party's ties with the UMP in 2011. After the 2012 parliamentary elections, Centrists and Radicals formed a separate group in the National Assembly, with 30 members to the UMP's 191. And on 21 October 2012, the Parti Radical and the Nouveau Centre federated into a single formation, the UDI, under Borloo's presidency. Independent from the UMP, the UDI is nevertheless committed to fighting elections and governing in coalition with it, reproducing the UDF's (often uneasy) alliance with the RPR before 2002. Bayrou and the MoDem then joined forces with the UDI under an umbrella organisation, The Alternative (Le Monde, 6 November 2012). The electoral cycle of spring 2014 suggested the success of this enterprise, despite Borloo's retirement in April for health reasons. The municipal elections showed that the Alternative could form a winning coalition with the UMP; the European elections, that the Alternative, with a consistently proEuropean policy and nearly half the UMP's vote, was more than a 'spare wheel' in the alliance.

The municipal elections suggested that the opposition offer was sufficiently diverse to attract moderates as well as hard-line right-wingers, but united enough to prevent the dispersal of 
votes. Of the 41 UMP mayors who won towns of over 30,000 inhabitants from the Left in 2014, 33 had done so with explicit Centrist backing, from the first ballot in 26 cases. Of their 10 Centrist counterparts, 8 had won with the support of the UMP, all from the first ballot (calculated from Le Monde, 25 March and 1 April 2014). This local success almost certainly presaged the return of a majority in the Senate in September 2014, after an interlude of just three years. But as the European elections showed, the opposition was far from having regained the public's confidence as a government-in-waiting.

Personality, policy, and scandal: a vulnerable opposition (A-head)

The opposition has three major handicaps to overcome to regain national credibility: its uncertain leadership, its policy divisions, and (in the UMP's case) an ever-denser web of scandal.

The leadership problem (B-head)

Leadership is at the heart of the Fifth Republic's presidentialised party system. Effective party leaders are credible presidential candidates, and vice versa. But both the Centrists and the UMP have suffered from a leadership problem since 2012.

The Centrists' difficulty is the simpler to outline. Their most high-profile figure, especially after Borloo's retirement, was indisputably Bayrou, who had led the UDF, twice held office as Education minister, twice run for the presidency, and, in March 2014, won election as mayor of Pau. But he had never reached a presidential second ballot, and his past record, especially his preference for Hollande in 2012, had earned him few friends (IFOP, 2012c). Among other centrist leaders, five - Hervé Morin, Chantal Jouanna, Rama Yade, Jean-Christophe Lagarde, 
and Yves Jégo - had held ministerial office under Sarkozy; none, however, has anything like Bayrou's name recognition or support (IFOP, 2014b; TNS-SOFRES, 2014b). In the absence of any obvious standard-bearer of their own, the Centrists may throw their weight behind an acceptable UMP candidate in 2017. In the meantime, however, the UDI scheduled its own, potentially divisive, leadership election for November 2014, with at least Morin and Lagarde promising to run and Borloo still aspiring to be kingmaker behind the scenes.

The UMP's leadership difficulties are greater, and the stakes higher, because it is one of two parties (with the Parti Socialiste) that can normally hope to win the presidency of the Republic (Grunberg and Haegel, 2007). But it is also what Angelo Panebianco (1988) has termed a 'weakly institutionalised' party, lacking clearly established procedures for reconciling the policy divisions and personal rivalries that are the stuff of party life. Moreover, as Haegel $(2012,135-7)$ observes, the symbiosis which developed over a decade between the UMP, the presidency, and the government made the move to opposition especially problematic.

The institutional weakness has been compounded by Sarkozy. After 2007 he engineered changes to the UMP's statutes, which now stated that when a UMP member became president of the Republic, the office of party president would lapse, leaving party management to its secretary-general and two assistants - under implicit guidance from the Élysée (Huertas, 2013, 27-9; UMP, 2014d). But the statutes offer no guide to what happens when the UMP loses the presidency. Does the former president simply return to his former party post? Does the secretary-general remain? Does the former president have any special claim to re-selection as a future candidate? The defeat of 2012 left these questions unresolved.

Worse, for two years Sarkozy maintained a deliberate uncertainty about his own intentions. Before May 2012 he had stated privately that he would leave politics if defeated. But his 
farewell speech was less clear: while 'my place can no longer be the same', he declared, he would still 'defend our ideas and convictions' (Sarkozy 2012). For the UMP, this created a situation without precedent under the Fifth Republic. Of Sarkozy's five predecessors, one (Pompidou) had died in office and three (de Gaulle, Mitterrand and Chirac) had chosen retirement. Only Giscard had been young enough (55 at his defeat in 1981) to seek a comeback, but his UDF was too much a federation of notables to help him much. By contrast, the UMP's Gaullist roots, and Sarkozy's practice since 2004, have made it a leader-focused party. No longer President of the Republic, Sarkozy apparently also renounced party leadership. He neither stepped back into the UMP presidency nor sought local office, as Giscard had in 1982. Quietly, though, he made sure to telephone selected UMP Deputies as they were re-elected in June 2012 ('Bonjour, c’est Nicolas') (Huertas, 2013, 103). 'Privately', Sarkozy made carefully-judged appearances at party meetings, or at his wife Carla Bruni's concerts (Le Monde, 30 January, 11 February 2014). This calculated teasing condemned his party to a future of permanent internal competition for the leadership. Even after his television interview of 2 July 2014, when his return was scarcely in doubt, its form and timing remained uncertain.

Six months after Sarkozy's defeat, the UMP held a chaotic, crooked, indecisive election to the revived party presidency. Six candidates stood, but the UMP's membership got a reasonably clear choice between the two front-runners: Sarkozy's long-suffering former Prime Minister, François Fillon, and Copé, UMP secretary-general since 2010. Both men sought to bury Sarkozy, but in different ways. Fillon aimed to distance himself, and the UMP, from Sarkozy's rightward turn, called for a critical 'inventory' of his presidency, and made a statesmanlike appeal for tough decisions to restore France's economy. Copé, by contrast, pleaded for a Droite décomplexée (Copé, 2012), and focused on law and order and immigration, reaching a dramatic climax with the claim that Moslems enforcing the Ramadan fast were snatching breakfast-time pains au chocolat from schoolchildren in Meaux. This 
resembled a continuation of Sarkozy's campaign, down to the body language (Latrous and Marteau, 156) - but without Sarkozy.

Starting with the support of no more than 25 per cent of UMP sympathisers in August to Fillon's 60 (IFOP, 2012a), Copé nevertheless took the presidency. One explanation was that the real vote, unlike the polls, was confined to members, more committed and more radical than sympathisers. But the campaign counted too. Both men wanted the UMP presidency to further their ambitions for 2017. But Fillon, never much of a party man, saw control of the UMP merely as a means to an end, whereas Copé actively relished running the apparatus. Fillon, recovering from a broken ankle sustained on holiday, ran a low-key campaign; Copé, as Sarkozy's spiritual heir, a hyperactive one. Fillon lunched with local notables, whom he took to be opinion-formers; Copé made a barn-storming appeal to the 'people' against the party’s ‘barons'. Those differences eroded Fillon's early lead.

Copé shaped his own victory in other ways, too. Unconstrained by the UMP's ambiguous statutes, he remained as secretary-general, and thus as de facto party leader. Fillon complained bitterly of this conflict of interest, with much justification. Copé's team mobilised full-time party workers for his campaign; organised dubious proxies on a massive scale; manipulated overseas votes; and ensured that polling stations were twice as numerous, per party member, in départements favourable to him than in those leaning to Fillon (Huertas, 2013, 7-12;

Barjon and Jeudy, 2013, 108-9; Latrous and Marteau, 2013, 31-5). The result - long queues, abandoned by some party members before they voted - was deliberately organised 'disorganisation'. Party officials who questioned these practices resigned in protest or were sacked (Barjon and Jeudy, 2013, 103).

This array of dirty tricks, plus an energetic, if demagogic, campaign, brought Copé close to a majority. To nail the outcome, Copé publicly claimed victory by 1,000 votes at $11.30 \mathrm{pm}$ on 
polling day, 18 November. In doing so he by-passed the Commission de Contrôle des Opérations Électorales (CoCoE), the party body responsible for declaring the result; voting returns had not even been fully counted. This opened a murderous month in which Fillon too claimed victory, having discovered uncounted returns from three French overseas territories; in which the weak-willed chairman of the CoCoE, Patrice Gélard, announced that the new votes 'reversed' the result, before confirming Copé's victory after all, and adding that in any case, 'Fraud is part of the historical tradition of certain party federations' (Barjon and Jeudy, 2013, 83-4); in which successive attempts at mediation, first by the UMP's first president, former prime minister Alain Juppé, and then by Sarkozy himself, broke on the rock of Copé's intransigence; in which Fillon, on 3 December, created his own parliamentary group, signalling his willingness to split the UMP; in which the Copé camp accused Fillon of 'fraud on an industrial scale', while Fillon declared that 'a political party is not a Mafia' (Le Monde, 23 November 2012); in which Copé, finally, agreed to negotiate after the threat of another former Prime Minister, Jean-Pierre Raffarin, to take his own supporters out of the UMP Senate group.

Raffarin brokered a deal on 17 December. Copé would keep the presidency pending a new election in September 2013; a 'collegial' leadership team including Fillon supporters would serve under him (the resulting 'Mexican army' included 20 vice-presidents, 12 assistant secretaries-general, and 13 delegates-general) (UMP, 2014c); and a committee would revise the UMP's statutes. That was enough for Fillon to bring his parliamentarians back to the UMP group. The statutes were reformed by a committee under Anne Levade, an impartial law professor. Presidential candidates would henceforth be nominated by a primary open to any declared UMP sympathiser, on the model pioneered by the Socialists in 2012. Candidates campaigning for the nomination, and for the UMP presidency, would have to relinquish their party functions. That met Fillon's conflict-of-interest complaint. 
With the UMP saved for the moment, the municipal election campaign proceeded in an atmosphere of truce; local elections, by definition, allow many winners (Le Monde, 25 January 2014). But there was neither reconciliation nor resolution. An electronic vote by party members in June 2013 had postponed the new election to the party presidency till Copé's term expired in November 2015; not even Fillon wanted another bruising contest so soon. With the municipal elections over, Fillon and Juppé voiced doubts about Copé's commitment to the more inclusive party regime, and complained of delays to the first meeting of a new bureau politique, the party's national executive voted in by the January 2014 National Council (Le Monde, 2 April 2014). When the bureau politique did meet, on 28 May, it forced Copé's resignation; his place was taken by a triumvirate of former prime ministers (Fillon, Raffarin, and Juppé) pending a new election in November 2014.

The 2012 crisis did lasting damage to the two main protagonists and the UMP. After the leadership election, 78 per cent of UMP sympathisers declared themselves disappointed, worried, or angry with their party; 75 per cent viewed the crisis as a mere clash of personal ambitions (IFOP, 2012d, 2012e). Positive opinions of Fillon dropped from 65 per cent to 50 in the last quarter of 2012, Copé's from 48 to 28. Copé was voted 'most annoying person of 2012' (by 81 per cent of respondents, and by 67 per cent of UMP sympathisers) amongst a panoply of political, sporting and television personalities - a rating he wore lightly, convinced that like Chirac and Sarkozy before him, he could only climb back (IFOP, 2012b, 2012f; Harris-Interactive-VSD, 2012; Latrous and Marteau, 2013, 73). But Copé's positive opinions in the IFOP polls have never returned to 40 per cent, nor Fillon's to 60.

Instead, UMP supporters looked to other contenders, and especially to the king across the water. As early as January 2013, 67 per cent of them wanted Sarkozy to return to politics and run for president in 2017. By July 2013, despite the Constitutional Council rejecting his 
campaign accounts, the figure was 82 per cent. In July 2014, with Sarkozy now under official judicial investigation for corruption, it was 78 per cent (IFOP, 2013a, 2013e, 2014a; BVA, 2014b). Against other possible candidates, he was preferred by 56 per cent of UMP supporters at the end of February 2013 (against 17 per cent for Fillon, 9 per cent for Juppé, and 4 per cent for Copé); even in June 2014, with the UMP mired in scandal, Sarkozy's support was still at 54 per cent, against 8 per cent for Fillon, a mere 1 per cent for Copé... and 22 per cent for Juppé (IFOP, 2014c). Still the activists' darling, despite everything, Sarkozy clearly had little time for party procedures, reformed or not: Hortefeux was surely voicing his master's views when he told Le Monde (4 June 2014) that a Sarkozy candidacy would impose itself 'naturally', without any primary.

But Sarkozy was also a more divisive figure than ever, as was shown by the contrast between his popularity and that of Juppé, who in 2013 overtook Fillon as the UMP's leading moderate. A deeply unpopular prime minister in Chirac's first term (1995-7), Juppé had been convicted in 2004 for putting RPR party workers on the Paris municipal payroll before 1995, when Chirac had been the capital's mayor. But his conduct then - accepting the court's decision, resigning his political offices (including the founding presidency of the UMP), and taking a two-year break from politics - won him a degree of respect, especially as he was assumed to be paying for Chirac. His return to public favour owed much, too, to his consensual role as mayor of Bordeaux, to which office he was triumphantly re-elected in March 2014.

When asked to express a preference between the former president and Juppé, UMP supporters gave Sarkozy a consistent two-to-one majority over four polls in 2013-14. But among the wider public, Juppé had a clear advantage, with 54-58 per cent of choices to Sarkozy’s 36-42 per cent (IFOP, 2014b). Even among broadly right-wing (as opposed to UMP) supporters he enjoyed a narrow lead on Sarkozy (CSA, 2014a, 2014b). And by summer 2014, he was easily 
France's most popular right-wing politician, or even, on some polls, the most populat of any camp (TNS SOFRES, 2014b).

Two years into the Hollande presidency, therefore, the UMP's leadership issue was as unresolved as ever. No fully accepted mechanism existed to choose either the party's president or its presidential nominee. The ruling triumvirate was denounced as illegitimate by Nadine Morano, a leading hard-line Sarkozy supporter (Le Monde, 2 June 2014). The Sarkozy-Juppé rivalry was superimposed on the Fillon-Copé contest, none of whose venom had been drawn. And behind the ill-contained personal rivalries were distinct visions of the party that the UMP should be.

Policy and strategy (B-head)

The centrists are not without strategic and policy uncertainties. Supporters of both UDI and MoDem strongly favour a closer union between their two parties. But like the electorates of many liberal parties (and the old UDF) they are divided between moderate, pro-European social and Christian democrats (roughly, MoDem) and right-wing liberals comfortable in coalition with conservatives (roughly, the UDI) (IFOP, 2013f, 2013g). Strategic tensions related to this division will intensify as the 2017 elections approach.

But the UMP faces larger policy issues. At their simplest, they are: should the UMP continue on the right-wing populist trajectory of Sarkozy's 2012 presidential campaign, pitching to farright voters on the FN's own policy terrain, or should it return to a more orthodox conservative identity? Party members had the opportunity to express their preferences in November 2012, when they were invited to choose, along with the party president, between six different motions intended to set the UMP's future course. But serious debate between rival projects was drowned out by a personalised leadership contest. And the correlation 
between votes for the two leading candidates and those for right-wing or moderate motions, though present, was weak (IFOP, 2012g).

The result offered comfort to both main camps. The more moderate motions, La droite sociale (22 per cent), France moderne et humaniste (18 per cent), and Les gaullistes en mouvement (12 per cent) had a narrow combined majority. But first place with nearly 28 per cent, and a clear moral victory, went to La droite forte, whose proposer Guillaume Peltier had been a spokesman for Sarkozy's 2012 campaign after starting out in politics with the FN. And under Copé's presidency of the UMP, the right-wing populist line flourished. Instead of the critical 'inventory' on the Sarkozy presidency demanded by Fillon, the party held a half-day convention (from which the Fillon camp stayed away) in praise of 'five years of action to improve the lives of French people', which outlined 'ten priorities' for building on the Sarkozy legacy and preparing the ground for the right-wing projet d'alternance of January 2014 (UMP, 2013).

To a degree, this corresponded to a radicalisation of right-wing voters in the wake of Hollande's election, as had occurred after Mitterrand's in 1981 (Haegel, 2012, 239-296). On many issues, and especially immigration, polls showed UMP supporters as closer to the FN's positions than to those of other parties, including the MoDem; only on the future of the euro was the UMP closer to the moderate mainstream (Table 1). Tolerance of immigrants, falling among all groups, had dropped fastest among UMP supporters. The proportion of respondents agreeing that 'Il faut passer d'une immigration subie à une immigration choisie' rose from 62 per cent in April 2006 to 86 per cent in October 2013; among UMP voters, it rose from 82 per cent to 96 . In the same period, those agreeing that 'more is done for immigrants than for the French' rose from 40 to 67 per cent among the general population- and from 45 to 86 per cent among UMP supporters (IFOP, 2013h). Logically, they also drew closer to the FN. Between 2003 and 2013, the proportion of UMP supporters considering the FN was an extreme right- 
wing party fell from 84 per cent to 67 ; those viewing it as a danger to democracy fell from 67 per cent to 49; and those considering it a 'useful' party rose from 53 per cent to 67 . Over half of UMP supporters in October 2013 viewed FN proposals on law and order, on immigration, and on safeguarding local public services as 'convincing'. By then 22 per cent of UMP supporters had already voted for the FN; a further 21 per cent felt tempted to do so in the future (IPSOS, 2013). And half of UMP supporters backed an electoral alliance with the FN for the 2014 municipal elections (TNS-SOFRES, 2014a).

Table 1. Party positions on political and social issues, 2014

\begin{tabular}{|c|c|c|c|c|}
\hline & \multicolumn{4}{|c|}{ Supporters of ... } \\
\hline & Left & MoDem & UMP & $\mathrm{FN}$ \\
\hline $\begin{array}{l}\text { France needs a 'real leader to put things } \\
\text { back in order' - agree }\end{array}$ & 63 & 80 & 98 & 100 \\
\hline Support the restoration of the death penalty & 22 & 25 & 60 & 79 \\
\hline $\begin{array}{l}\text { The unemployed could find work if they } \\
\text { really wanted to - agree }\end{array}$ & 31 & 42 & 63 & 68 \\
\hline $\begin{array}{l}\text { There are too many foreigners in France - } \\
\text { agree }\end{array}$ & 39 & 57 & 82 & 98 \\
\hline $\begin{array}{l}\text { We don't feel at home in France as we used } \\
\text { to - agree }\end{array}$ & 40 & 54 & 75 & 94 \\
\hline $\begin{array}{l}\text { Anti-white racism is common in France - } \\
\text { agree }\end{array}$ & 38 & 40 & 63 & 82 \\
\hline
\end{tabular}




\begin{tabular}{|l|c|c|c|c|}
\hline To cut unemployment, the number of & & & & \\
immigrants in France should be reduced - & 26 & 34 & 58 & 77 \\
agree & 23 & 19 & 21 & 66 \\
\hline France should leave the euro and return to & & & & \\
\hline
\end{tabular}

Source: IPSOS/Steria/CEVIPOF, 2014, 25, 27, 49, 86, 88, 89.

On the narrow issue of relations with the FN, there is much common ground within the UMP leadership. No leading figure, moderate or populist, wants an alliance. Fillon claimed that he, and not Copé, opposed one on principle (Le Monde, 31 March 2014); but even Copé has stressed the gulf between the UMP's core values and the FN's (Copé, 2012, 184-5). Equally, no UMP leader now backs a 'republican pact' with the Socialists to defeat FN candidates at run-off ballots. These shared views do not, however, extend to the programme. Copé, Peltier, and Mariton connected with the social movements of 2013; Fillon and Juppé did not. The UMP project commands no support from moderates. Juppé stayed away from the National Council meeting that ratified it; Fillon and moderates like François Baroin, Nathalie Kosciusko-Morizet and Xavier Bertrand appeared, but took no part in the vote (Le Monde, 25 January 2014). The division was reflected among UMP supporters: in June 2014, 57 per cent wanted Sarkozy to run for president on a clearly right-wing programme but 34 per cent preferred moderation (IFOP, 2014d); asked about the UMP's future positioning in general, 50 per cent favoured a move rightwards, but 45 per cent preferred a shift to the centre (BVA, 2014a). And the UMP's European election campaign was unsuccessful in part because the party, unlike the Centrists, had no united message on Europe (Le Monde, 30 April 2014). Policy as well as personality will continue to mark future leadership competition within the UMP. 
Party competition and funding scandals (B-head)

'Retracer l'histoire du gaullisme', wrote Philippe Madelin (2001, 12), 'c'est raconter la saga de ses finances.' In this if in few other respects, the UMP had been true to its Gaullist roots, and Sarkozy central to that fidelity. Haegel has observed that he remodelled the party as a business enterprise, borrowing techniques such as focus groups and performance targets from the corporate world, but also blurring the frontier between private profit and the public interest the UMP claimed to promote (Haegel, 2012, 167-171; Haegel, 2014). Within the Gaullist party tradition, though, that was not wholly new.

Space precludes mention of every judicial investigation involving Sarkozy (Le Monde, 3 July 2014); but they cover each of the presidential campaigns in which he has played a part Édouard Balladur's in 1995 (which Sarkozy directed) and his own in 2007 and 2012. The judiciary have inquired into the possible use of kickbacks on arms sales to Pakistan to finance the Balladur candidacy; into possible funding for Sarkozy in 2007 from Libya and (though this file was closed without charges in October 2013) from the Loréal heiress Liliane Bettencourt; and into a series of infringements of campaign finance rules in 2012, which have not only damaged the UMP politically but left it nearly bankrupt.

Sarkozy's 2012 campaign accounts were rejected first by the National Commission for Campaign Accounts and Political Finance and then, on appeal, by the Constitutional Council. The President's team had omitted to declare certain receipts and expenses on the ground that they served the UMP rather than the presidential campaign directly, or that normal presidential expenses covered them. As adjusted by the Constitutional Council, Sarkozy's spending, at 22,975,118 euros, was 7.8 per cent higher than declared, and, crucially, 2.1 per cent higher than the maximum authorised for candidates receiving state campaign finance. 
Sarkozy was required both to reimburse the advance on expenses of 153,000 euros paid from the public purse to all candidates, and to pay a penalty corresponding to his overspend of 363,615 euros. Above all, he was disqualified from the normal state reimbursement of half his total expenses to which candidates respecting the spending ceiling are entitled (Conseil Constitutionnel, 2013; Le Monde, 5 July 2013). The resulting shortfall of 11 million euros came on top of a 10 million euro drop in UMP income from public finance, corresponding to its loss of votes and seats at the 2012 legislative elections. It testifies to the determination of candidate and party, and to UMP supporters' long purses, that a 'Sarkothon' raised 10.2 million euros of donations in six weeks (Le Monde, 16 August 2013).

There the matter rested until February 2014, when Le Point published claims that Event et Cie, which had organised 43 meetings for the campaign, had overbilled its services (which had cost 8 million euros). Event et Cie was a subsidiary of Bygmalion, a political communications consultancy headed by Bastien Millot. Millot had been Copé's directeur de cabinet in the town hall of Meaux and in his ministerial functions in 2002-5. Copé was therefore suspected of having used Sarkozy's campaign to favour his own political friends ( $L e$ Monde, 27 February 2014), prompting a judicial investigation into a possible false invoicing system, involving sums up to 10 million euros.

Three months later, Jérôme Lavrilleux, Copé's former directeur de cabinet in the UMP, confirmed on television that a system of double accounting had been set up, allowing the UMP to cover part of Sarkozy's expenses. Estimates of Sarkozy's total campaign spend now reached 33 million according to Bygmalion and 39 million according to Mediapart, an on-line news service (Le Monde, 28 May, 6 June, 4 July 2014). Lavrilleux’s revelations inevitably prompted speculation as to where the missing millions had gone. The Sarkozy camp denied all knowledge, hinting that Copé had embezzled the money to set up a slush fund for his own future presidential bid. Copé's entourage, including Lavrilleux, by contrast, suggested a 
campaign that had run out of control, with too many meetings, too many gadgets, too many special effects, too many trainloads of activists, too many last-minute (and premium-rate) orders (Marianne, 13-19 June 2014; Le Monde, 6 June 2014). Neither interpretation, of course, inspired confidence in the UMP's capacity to govern France.

As the Bygmalion affair gathered pace, Sarkozy himself was held for questioning for 15 hours - a first for an ex-president - before being placed under official investigation in the early morning of 2 July. The specific accusation, gleaned from taps on Sarkozy's private telephones in 2013-14, was that he had illegally sought to influence senior French judges, notably in the Court of Cassation, via his lawyer Thierry Herzog, to keep him directly informed of investigations into the Bettencourt and Libyan affairs. Less than a week later, a further investigation was launched into the payment by the UMP of his 363,615 euros penalty, for which he had been personally liable (Le Monde, 7 July 2014).

The fall-out from the affaires, beginning with Copé's forced resignation the day after Lavrilleux's television appearance, showed no sign of abating after six weeks. Sarkozy went on television on the evening of 2 July to cast himself as the innocent victim of politicised judges. His inner circle rallied to him but support elsewhere in the party was luke-warm. The Sarkozy and Copé camps, united in opposition to the UMP's temporarily ruling triumvirate, barely tolerate one another. Sarkozy's attack on the judiciary earned him rebukes from Juppé (who had taken his own conviction on the chin) but also from Jean-Louis Debré, president of the Constitutional Council and former RPR minister (Le Monde, 5 July 2014). Perhaps more strikingly, Sarkozy's standing with the wider public appeared, finally, to have been dented: in the three months to July 2014, his CSA ratings dropped from 44 to 34 per cent, his worst figure since his presidential defeat (CSA, 2014b). That his support had not collapsed completely reflects the loyalty that Sarkozy still inspires. But even his determination will be challenged if he tries, as seems likely, simultaneously to win back the presidency and to tough 
out a judicial investigation. The UMP rank-and-file, meanwhile, had begun to query their own contributions to the 'Sarkothon', when the candidate himself did not pay his own fines and when 24,000 euros of air tickets for the UMP president's wife - Mme Copé - were covered by the party (Le Monde, 3 and 7 July 2014). Among the wider public, 48 per cent of poll respondents - including 32 per cent of UMP sympathisers - considered that the UMP should be shut down and replaced by another party (BVA, 2014c).

Aside from its more political impact, Sarkozy's campaign and Bygmalion's billing had damaged the UMP's finances. At the end of 2007, the year of Sarkozy's election, the UMP had run a loss of 9.9 million euros, or 17 per cent of income, and carried debts of nearly 50 million euros ( 85 per cent of income); that figure had been wrestled down to 19.4 million, or 36 per cent of income, by 2009. At the end of 2012, however, losses reached 39.6 million euros, or 67.8 per cent of income (CNCCFP, 2014 ; Le Monde, 7 July 2014). In that context, the financial audit requested by the triumvirate in June 2014, while it might have the added advantage of discrediting political opponents, was also a prudential necessity. It revealed a debt of some 74.5 million, or 128 per cent of income, a level just compatible with the UMP's survival if economies were made and mortgage repayments extended (Le Monde, 9 July 2014; Le Carard Enchaîné, 9 July 2014). The UMP has a pressing financial as well as a political interest in winning in 2017.

Conclusion (A-head)

In December 1976, Jacques Chirac had launched the RPR as a revived neo-Gaullist party and a vehicle for his own future presidential campaigns. When he closed it down 26 years later it had become a toxic brand, lacking activists and contaminated by internecine rivalries and financial scandals (Knapp, 2004, 87, 267). The UMP, the successor party, has taken less than half the time to reach a comparable position. To a degree, the same causes have produced the 
same effects: a leadership-focused party, with a historic tendency to confuse political finance and private profit, lacking a shared and respected body of rules, and finally lacking confidence in its leader. The acceleration has been largely the work of Sarkozy himself, a president more fascinated than any of his predecessors with speed and with communication and the wealth that goes with it (Duhamel and Field, 2008). But the UMP's fate, even to its detractors, should not be a matter for indifference. On the contrary, the importance for French democracy of a healthy UMP with a strong presidential candidate, and a working alliance with the Centre, could hardly be higher. The alternative, given the Left's continuing discredit, is for the FN to become the first party of France, and not only at the European elections.

Bachelot, R.. 2012. À Feu et à Sang. Paris: Flammarion.

Barjon, C., and B. Jeudy. 2013. Le coup monté Paris: Plon.

BVA. 2014a. L'avenir de 1'UMP, 26-27 June. http://www.bva.fr/data/sondage/sondage_fiche/1571/fichier_bva pour_i tele_- cqfd_le parisien__lavenir_de lumpce3ef.pdf. Accessed 6 July 2014.

BVA. 2014b. Le retour de Nicolas Sarkozy. 3-4 July. http://www.bva.fr/data/sondage/sondage_fiche/1577/fichier_bva pour_i tele_-_cqfd_le_parisien___le_retour_de_nicolas_sarkozy4ed2a.pdf. Accessed 6 July 2014.

BVA. 2014c. La crise à 1'UMP, 10-11 July. http://www.bva.fr/data/sondage/sondage_fiche/1584/fichier_bva pour_i tele_- cqfd_le parisien__ la crise a lump4a099.pdf. Accessed 12 July 2014.

Canard Enchaîné, Le, 2013. Les Nouveaux Réacs. Après la manif pour tous, à droite toute! Paris: Éditions Maréchal/Le Canard Enchaîné (Les Dossiers du Canard). 
Chiche, J., and E. Dupoirier. 2013. De la défaite de Nicolas Sarkozy au triste dixième anniversaire de 1'UMP. In Le Vote normal. Les élections présidentielle et législatives d'avril-mai-juin 2012, ed.P. Perrineau, 193-226. Paris: Presses de Sciences Po.

CNCCFP (Commission Nationale des Comptes de Campagne et des Financements Politiques). 2014. Publication générale des comptes des partis et groupements politiques au titre de l'exercice 2012. Jounal Officiel, 22 January, 680-681.

Conseil Constitutionnel. 2013. Décision n² 2013-156 PDR du 04 juillet 2013. http://www.conseil-constitutionnel.fr/conseil-constitutionnel/francais/lesdecisions/acces-par-date/decisions-depuis-1959/2013/2013-156-pdr/decision-n-2013156-pdr-du-04-juillet-2013.137580.html. Accessed 27 June 2014.

Copé, J.-F. 2012. Manifeste pour une droite décomplexée. Paris: Fayard.

CSA. 2014a. Observatoire CSA/Les Échos/Radio Classique, 1-2 April 2014. http://www.csa.eu/multimedia/data/sondages/data2014/opi20140402-csa-les-echos-1observatoire-politique-avril-2014.pdf. Accessed 7 July 2014.

CSA. 2014b. Observatoire CSA/Les Échos/Radio Classique, 1-2 July 2014. http://www.csa.eu/multimedia/data/sondages/data2014/opi20140702-csa-les-echosradio-classique-1-observatoire-politique-juillet-2014.pdf. Accessed 7 July 2014.

Grunberg, G., and F. Haegel. 2007. La France vers le bipartisme? La présidentialisation du PS et de l'UMP. Paris: Presses de Sciences Po.

Duhamel, O., and M. Field. 2008. Le Starkozysme. Paris: Le Seuil.

Haegel, F. 2012. Les droites en fusion. Transformations de l'UMP. Paris: Presses de Sciences Po.

Haegel, F. 2014. 'L’UMP en plein délitement', Le Monde, 12 March. 
Harris-Interactive-VSD. 2012. Les personnalités qui agacent les Français - Vague 3, December. http://www.harrisinteractive.fr/news/2012/26122012.asp. Accessed 28 June 2014.

Huertas, H. 2013. La Guerre des deux droites. Paris, L'Archipel, 2013.

IFOP. 2012a. La personnalité préférée pour diriger l'UMP, 27-31 August. http://www.ifop.com/?option=com publication\&type=poll\&id=1962. Accessed 27 June 2014.

IFOP. 2012b. Tableau de bord politique: les personnalités. 6-7 September. http://www.ifop.com/?option=com publication\&type=poll\&id=1975. Accessed 27 June 2014.

IFOP. 2012c. La personnalité politique qui incarne le mieux les idées et les valeurs du centre. 2-4 October. http://www.ifop.com/?option=com_publication\&type=poll\&id=2000. Accessed 27 June 2014.

IFOP. 2012d. Les raisons expliquant la situation actuelle à 1'UMP. 22-23 November. http://www.ifop.fr/media/poll/2061-1-study_file.pdf. Accessed 27 June 2014.

IFOP. 2012e. Les réactions face à la crise de 1'UMP. 29-30 November. http://www.ifop.com/?option=com_publication\&type=poll\&id=2069. Accessed 27 June 2014.

IFOP. 2012f. Tableau de bord politique: les personnalités. 6-7 December. http://www.ifop.com/?option=com_publication\&type=poll\&id=2077. Accessed 27 June 2014.

IFOP. 2012g. Focus no. 73. Quelles enseignements tirer de la géographie des votes aux élections internes de l'UMP ? 4 December. 
http://www.ifop.com/?option=com publication\&type=publication\&id=523. Accessed 27 June 2014.

IFOP. 2013a. Les sympathisants UMP et le souhait de retour de Nicolas Sarkozy dans la vie politique, 20 December 2012-5 January 2013 ; http://www.ifop.fr/?option=com publication\&type=poll\&id=2107. Accessed 28 June 2014.

IFOP. 2013b. Les Français et les droits des couples homosexuels, 4-6 February; http://www.ifop.fr/?option=com publication\&type=poll\&id=2147. Accessed 28 June 2014.

IFOP. 2013c. Les Français face à la PMA, la GPA, et l'homoparentalité, 27 February-1 March. http://www.ifop.fr/?option=com publication\&type=poll\&id=2193. Accessed 28 June 2014.

IFOP. 2013d. La société française et l'homosexualité, série Collectors 19, June. http://www.ifop.fr/?option=com_publication\&type=publication\&id=595. Accessed 28 June 2014.

IFOP. 2013e. Le souhait et le pronostic de candidature de Nicolas Sarkozy à la présidentielle de 2017 après le rejet de ses comptes de campagne, 5-6 July. http://www.ifop.com/?option=com_publication\&type=poll\&id=2288. Accessed 29 June 2014.

IFOP. 2013f. Focus 95, L'électorat de l’UDI: plus proche de l’UMP ou du MoDem? September. http://www.ifop.com/?option=com_publication\&type=publication\&id=618 Accessed 27 June 2014.

IFOP. 2013g. L'opportunité d'une union entre le MoDem et l’UDI. 18-20 September. http://www.ifop.com/?option=com publication\&type=poll\&id=2345. Accessed 27 June 2014. 
IFOP. 2013h. Les Français et l'immigration. 23-25 October. http://www.ifop.com/?option=com publication\&type=poll\&id=2393. Accessed 27 June 2014.

IFOP. 2014a. Les Français et la perspective du retour de Nicolas Sarkozy, 2-15 May. http://www.ifop.fr/media/poll/2662-1-study file.pdf. Accessed 29 June 2014.

IFOP. 2014b. Tableau de bord politique: les personnalités. 6-7 June. http://www.ifop.fr/?option=com_publication\&type=poll\&id=2694. Accessed 6 July 2014.

IFOP. 2014c. La candidature préférée des sympathisants UMP pour 2017. 11-13 June. http://www.ifop.com/?option=com_publication\&type=poll\&id=2703. Accessed 27 June 2014.

IFOP. 2014d. Les préférences concernant le programme politique de Nicolas Sarkozy. 26-27 June. http://www.ifop.com/media/poll/2718-1-study_file.pdf. Accessed 6 July 2014.

IPSOS. 2013. Les Français et le Front National dans la perspective des élections municipales de 2014, 15-16 November. http://www.ipsos.fr/sites/default/files/attachments/les_francais_et_le_fn.pdf. Accessed 7 July 2014.

IPSOS/Steria/CEVIPOF. 2014. 'Fractures françaises, Vague 2', 8-14 January 2014. http://www.ipsos.fr/sites/default/files/attachments/les_francais_et_le_fn.pdf. Accessed 7 July 2014.

Knapp, A. 2004. Parties and the Party System in France: a Disconnected Democracy? Basingstoke: Palgrave.

Kolinsky, E. 1987. Introduction. In Opposition in Western Europe, ed, E. Kolinsky, 1-7. Beckenham, Kent: Croom Helm. 
Latrous N. and J.-B. Marteau. 2013. Bal Tragique à l'UMP. Coups bas, fraudes et trahisons Paris: Flammarion.

Madelin, P. 2001. Le gaullistes et l'argent. Paris : Éditions de l'Archipel.

Panebianco, A. 1988. Political Parties: Organisation and Power. Cambridge: Cambridge University Press.

Perrineau, P. 2012. L'UMP en crise, l'UDI à l'offensive, Le Figaro, 27 November.

Piar, C. 2013. Des campagnes sous l'emprise de la conjoncture. In Le Vote normal. Les élections présidentielle et législatives d'avril-mai-juin 2012, ed. P. Perrineau, 25-41. Paris: Presses de Sciences Po.

RPR (Rassemblement pour la République). 1984. Libres et Responsables : Programme de Gouvernement. Paris: Flammarion.

Sarkozy, N. 2012. Discours de Nicolas Sarkozy à la Mutualité, 6 mai 2012. http://www.u-mp.org/actualites/a-la-une/discours-de-nicolas-sarkozy-a-la-mutualite-6530605. Accessed 6 July 2014.

Tartakowsky, D. 2013. Les Droites et la rue. Histoire dune ambivalence de 1880 à nos jours. Paris: La Découverte.

TNS-SOFRES. 2014a. Baromètre d'Image du Front National, 30 January-3 February. http://www.tns-sofres.com/etudes-et-points-de-vue/barometre-2014-dimage-du-frontnational. Accessed 28 June 2014.

TNS-SOFRES. 2014b. Baromètre politique, juillet 2014 (26-30 June 2014). http://www.tnssofres.com///sites/default/files/2014.07.03-baro-figmag.pdf. Accessed 6 July 2014.

UMP (Union pour un Mouvement Populaire). 2013. Nos idées: 5 ans d'action. http://www.um-p.org/nos-idees/5-ans-daction. Accessed 7 July 2014. 
UMP. 2014a. États Généraux de l'UMP. http://www.etats-generaux-ump.fr/ . Accessed 27 June 2014.

UMP. 2014b. Nos mesures d'urgence. http://www.u-m-p.org/actualites/a-la-une/redressonsla-france-nos-mesures-durgence-103882701. Accessed 27 June 2014.

UMP. 2014c. Organisation. http://www.u-m-p.org/notre-parti/organisation/les-instancesnationales. Accessed 27 June 2014.

UMP. 2014d. Statuts, article 48. http://www.u-m-

p.org/sites/default/files/media/documents/les-statuts2.pdf. Accessed 27 June 2014. 